\title{
Sistem Informasi Nilai Siswa Berbasis Web di SMK Karya Guna Jakarta
}

\author{
Muhammad Lomo Niroha, Mochammad Djaohar, Lipur Sugiyanta \\ Mahasiswa Prodi Pendidikan Teknik Informatika dan Komputer, Teknik Elektro, FT - UNJ \\ ${ }_{2,3}$ Dosen Prodi Pendidikan Teknik Informatika dan Komputer, Teknik Elektro, FT - UNJ
}

\begin{abstract}
Abstrak
Sistem informasi nilai siswa berbasis web merupakan suatu sistem yang memberikan informasi laporan nilai siswa secara online yang berupa laporan nilai serta informasi data siswa yang bersangkutan dengan berbasiskan web sehingga membantu kecepatan dan kualitas dalam penyampaian informasi. Permasalahan yang terjadi dalam pengolahan nilai siswa di SMK Karya Guna Jakarta saat ini masih bersifat konvensional, dimana siswa dan wali siswa hanya bisa melihat hasil dari kemampuan siswa tersebut pada akhir masa pembelajaran atau yang kita kenal dengan istilah pembagian raport siswa. Penelitian ini bertujuan untuk membangun suatu sistem informasi nilai yang mempermudah pengecekan, pencatatan dan laporan data nilai siswa yang terkomputerisasi. Dengan berbasiskan web maka informasi data nilai siswa dapat diakses kapan saja. Sistem menggunakan multiuser yang terdiri dari administrator, guru, orang tua dan siswa. Metode yang digunakan adalah

salah satu metode pengembangan perangkat lunak, yaitu metode waterfall. Program yang dihasilkan dalam sistem ini adalah sistem informasi nilai siswa berbasis web dengan menggunakan bahasa pemrograman PHP dan database MySQL.
\end{abstract}

\section{Kata Kunci: Nilai Siswa, Pengolahan Data, Sistem Informasi, Web}

\section{Pendahuluan}

\section{Latar Belakang}

Di tengah maraknya perkembangan teknologi informasi saat ini, pengembangan teknologi untuk edukasi terus dikembangkan. Hal ini dikarenakan semakin berkembangnya teknologi informasi dalam mendukung kemajuan pertukaran informasi yang semakin dominan di masyarakat saat ini.

Di kota Jakarta masih ada beberapa lembaga pendidikan pemerintah maupun swasta yang belum memanfaatkan teknologi yang sudah ada, dikarenakan keterbatasan fasilitas dan sumber daya manusia. Tanpa terkecuali di SMK Karya Guna Jakarta, teknologi informasi diharapkan tidak hanya sekedar mendukung pengembangan pendidikan saja, namun lebih dari itu teknologi informasi diharapkan dapat memberikan pemecahan pada permasalahan pendidikan dan informasi yang ada di SMK Karya Guna Jakarta.

Sebuah lembaga pendidikan tidak lepas dengan kurikulum yang tugasnya adalah menangani maupun mengawasi yang berkaitan dengan fasilitas sarana dan prasarana pendidikan yang dibutuhkan oleh sekolah guna menunjang lancarnya proses belajar mengajar.

Namun seiring dengan kemajuan teknologi ditambah dengan meningkatnya gaya hidup mobile.
Proses pemantauan nilai akademik siswa pada sistem yang sedang berjalan pada SMK Karya Guna Jakarta dilakukan dengan cara yang konvensional, dimana siswa dan wali siswa hanya bisa melihat hasil dari kemampuan siswa tersebut pada akhir masa pembelajaran atau yang kita kenal dengan istilah pembagian raport siswa.

SMK Karya Guna Jakarta memang mempunyai tantangan tersendiri dalam mengembangkan sistem informasinya. Kendala yang dihadapi tentulah tidak akan sama dengan sekolah lain. SMK Karya Guna Jakarta terdiri dari beberapa kompetensi keahlian dengan jumlah siswa yang terus bertambah setiap tahunnya. Sebenarnya inilah tantangan terbesar SMK Karya Guna Jakarta dalam menyampaikan jaminan informasi yang tepat dan akurat.

Banyak hal dari sistem informasi di SMK Karya Guna Jakarta yang masih membutuhkan pemecahan permasalahan. Salah satunya adalah informasi nilai siswa. Pengolahan informasi nilai siswa adalah sebuah pekerjaan yang membutuhkan ketelitian karena di dalamnya terdapat banyak sekali data yang harus diolah. Sering kali data - data tersebut tercantum tidak beraturan serta dengan proses pekerjaan yang lama dan tidak tepat waktu sehingga administrasi ataupun arsip yang ada menjadi tidak tertib dan tidak teratur. Hal itu menyebabkan banyak sekali kendala serta 
permasalahan yang harus dihadapi dalam penyampaian informasi seperti terjadi kesalahan terhadap hasil pekerjaan dan terlambatnya penyampaian informasi tersebut.

Semua hal tersebut tentunya membutuhkan suatu program yang bisa membuat pekerjaan tersebut lebih efektif, efisien, cepat dan mudah sehingga dapat memberikan informasi dengan tepat dan akurat.

Berdasarkan penjelasan di atas maka Penulis mencoba membuat sebuah "Sistem Informasi Nilai Siswa Berbasis Web di SMK Karya Guna Jakarta”.

\section{Dasar Teori}

\subsection{Sistem}

Sistem dapat diartikan sebagai suatu kumpulan atau himpunan dari unsur atau variabel - variabel yang saling terorganisasi, saling berinteraksi, dan saling bergantung satu sama lain. ${ }^{1}$

Sistem dapat didefinisikan dengan pendekatan prosedur dan dengan pendekatan komponen. Dengan pendekatan prosedur, sistem dapat didefinisikan sebagai kumpulan dari prosedur - prosedur yang mempunyai tujuan tertentu. Sedang dengan pendekatan komponen, sistem dapat didefinisikan sebagai kumpulan dari komponen yang saling berhubungan satu dengan yang lainnya membentuk satu kesatuan untuk mencapai tujuan tertentu. ${ }^{2}$

Sistem adalah sebuah tatanan yang terdiri atas sejumlah komponen fungsional (dengan tugas/fungsi khusus) yang saling berhubungan dan secara bersama - sama bertujuan untuk memenuhi suatu proses/pekerjaan tertentu. $^{3}$

Sistem dapat diartikan sebagai kumpulan elemen - elemen yang saling berkaitan dan bertanggung jawab untuk memproses input (masukan) sehingga menghasilkan output (keluaran).

\subsection{Informasi}

Sebelum memahami konsep informasi perlu diketahui dulu pengertian data. Data berasal dari kata "datum" yang berarti fakta yang mengandung arti pengolahan data dengan menggunakan computer dikenal dengan nama Pengolahan Data Elektronik (PDE) atau Electronic Data Processing (EDP). Data merupakan kumpulan kejadian yang diangkat dari suatu kenyataan. Data dapat berupa simbol - simbol, gambar - gambar, kata - kata, angka - angka, huruf - huruf yang menunjukkan suatu ide, objek, kondisi atau situasi. Data merupakan bahan yang akan

\footnotetext{
${ }^{1}$ Hanif Al Fatta, Analisis dan Perancangan Sistem Informasi, (Yogyakarta: ANDI, 2007), hlm. 3.

2 Jogiyanto, Sistem Teknologi informasi, (Yogyakarta: ANDI, 2005), hlm. 34

${ }^{3}$ Kusrini, Strategi Perancangan dan Pengelolaan Basis Data. (Yogyakarta: ANDI, 2007), hlm. 11.
}

diolah menjadi suatu bentuk yang lebih berguna dan bermanfaat.

Proses pengolahan data ada tiga, yaitu :

1. Input, yaitu dilakukannya proses pemasukan data ke dalam proses computer lewat alat input (input device).

2. Processing, yaitu dilakukannya proses pengolahan data yang sudah dimasukkan, yang dilakukan oleh alat pemroses (process device) yang dapat berupa proses perhitungan, perbandingan, pengendalian atau pencarian di penyimpanan (storage).

3. Output, yaitu dilakukannya proses menghasilkan keluaran dari hasil pengolahan data ke alat keluaran (output device) yaitu berupa informasi.

Gambar 2.1 Gambaran umum pengolahan data.

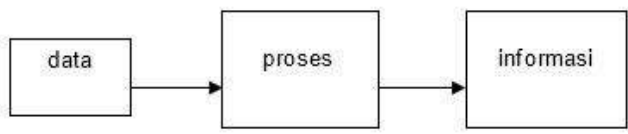

Gambar 2.1. Pengolahan Data.

Informasi mempunyai tingkat kualitas yang ditentukan beberapa hal, antara lain :

a. Relevan (relevancy)

Berarti informasi harus memberikan manfaat bagi pemakainya. Relevansi informasi untuk tiap-tiap orang satu dengan yang lainnya berbeda.

b. Akurat (accuracy)

Informasi harus bebas dari kesalahankesalahan dan tidak bias atau menyesatkan, dan harus jelas mencerminkan maksudnya. Ketidakakuratan dapat terjadi karena sumber informasi (data) mengalami gangguan atau kesengajaan sehingga merusak atau merubah data - data asli tersebut.

Komponen akurat :

1) Completeness

Berarti informasi yang dihasilkan atau dibutuhkan harus memiliki kelengkapan yang baik, karena bila informasi yang dihasilkan sebagian-sebagian tentunya akan mempengaruhi dalam pengambilan keputusan atau menentukan tindakan secara keseluruhan, sehingga akan berpengaruh terhadap kemampuannya untuk mengontrol atau memecahkan suatu masalah dengan baik. 2) Security

Masalah keamanan merupakan salah satu aspek terpenting pada sebuah sistem informasi. Desain sistem yang baik tidak meninggalkan lubang - lubang yang memungkinkan terjadinya penyusupan setelah sistem tersebut siap dijalankan. ${ }^{4}$

c. Tepat waktu (timeliness)

\footnotetext{
${ }^{4}$ Dony dan Ariyus, Computer Security, (Yogyakarta: ANDI, 2006), hlm. 26.
} 
Informasi yang dihasilkan atau dibutuhkan tidak boleh terlambat (usang). Informasi yang usang tidak mempunyai nilai yang baik, sehingga kalau digunakan sebagai dasar dalam pengambilan keputusan akan berakibat fatal atau kesalahan dalam keputusan dan tindakan. Kondisi demikian menyebabkan mahalnya nilai suatu informasi, sehingga kecepatan untuk mendapatkan, mengolah dan mengirimkannya memerlukan teknologi teknologi terbaru.

Dapat disimpulkan bahwa informasi adalah data yang sudah diolah, dibentuk atau dimanipulasi sesuai dengan keperluan tertentu, atau hasil dari pengolahan data yang secara prinsip memiliki nilai atau value yang lebih dibandingkan data mentah.

Jadi Sistem Informasi adalah kombinasi dari teknologi informasi dan aktivitas orang yang menggunakan teknologi itu untuk mendukung operasi dan manajemen.

\subsection{Database}

Basis data (database) adalah kumpulan dari data yang saling berhubungan satu dengan yang lainnya, tersimpan di perangkat keras komputer dan digunakan perangkat lunak untuk memanipulasinya. ${ }^{5}$

Dengan adanya komputer, data dapat disimpan dalam media pengingat yang disebut hard disk. Dengan menggunakan media ini, kehadiran kertas yang digunakan untuk menyimpan data dapat dikurangi. Selain itu, data menjadi lebih cepat untuk diakses terutama kalau dikemas dalam bentuk database.

Secara sederhana database (basis data) dapat diungkapkan sebagai suatu pengorganisasian data dengan bantuan komputer yang memungkinkan data dapat diakses dengan mudah dan cepat. Dalam hal ini, pengertian akses dapat mencakup pemerolehan data maupun pemanipulasian data, seperti menambah dan menghapus data. ${ }^{6}$

Jadi database adalah pengorganisasian sekumpulan data yang saling terkait sehingga memudahkan aktifitas untuk memperoleh informasi. Database dimaksudkan untuk mengatasi permasalahan pada sistem yang memakai pendekatan berbasis berkas.

\subsection{Web}

World Wide Web (WWW), sering disingkat dengan $w e b$, adalah suatu layanan di dalam jaringam internet yang berupa ruang informasi. Dengan adanya web, user dapat memperoleh atau menemukan informasi yang diinginkan dengan cara

\footnotetext{
${ }^{5}$ Jogiyanto, op. cit. hlm. 46.

${ }^{6}$ Abdul Kadir, Dasar Aplikasi Database MySQL Delphi,

(Yogyakarta: ANDI, 2006), hlm. 2.
}

mengikuti link (hyperlink) yang disediakan di dalam dokumen yang ditampilkan oleh aplikasi web browser. $^{7}$

Gambar 2.2 Cara kerja web secara umum.

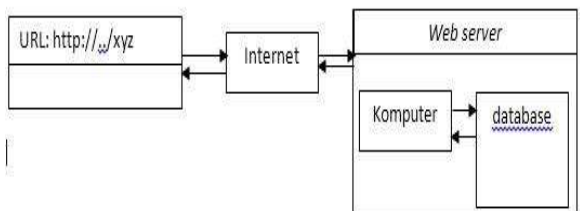

Gambar 2.2 cara kerja web

Web (website) atau juga situs, dapat diartikan sebagai kumpulan halaman - halaman yang digunakan untuk menampilkan informasi teks, gambar diam atau bergerak, animasi, suara, dana tau gabungan dari semuanya itu baik yang bersifat statis maupun dinamis yang membentuk satu rangkaian bangunan yang saling terkait dimana masing masing dihubungkan dengan jaringan - jaringan halaman (hyperlink).

\section{Metodologi}

Metode penelitian yang digunakan pada adalah salah satu metode pengembangan sistem, yaitu metode pengembangan sistem waterfall. Tahapan - tahapan dari metode waterfall yang diterapkan, yaitu:

1) Perencanaan Sistem (System Planning/ Requirements Analysis).

2) Perancangan Sistem (Designing).

3) Implementasi Rancangan (Coding).

4) Penerapan dan Pengujian (Integration and Testing/verification).

5) Pemeliharaan (Maintenance).

\section{Hasil dan Analisis}

\subsection{Implementasi Rancangan antarmuka}

Implementasi rancangan antarmuka halaman utama.

Gambar 4.1 Halaman login.

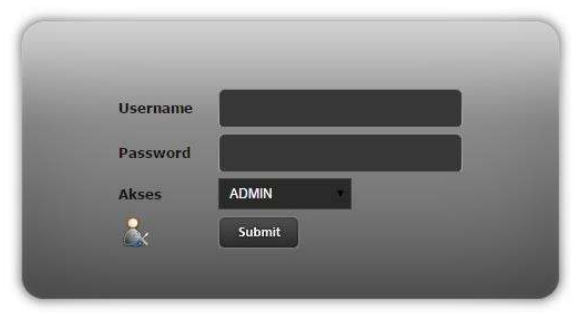

Gambar 4.1 Halaman Login.

Gambar 4.2 Halaman Input mata pelajaran.

\footnotetext{
${ }^{7}$ Budi Raharjo, Belajar Pemrograman Web, (Bandung: Modula, 2011), hlm. 2.
} 


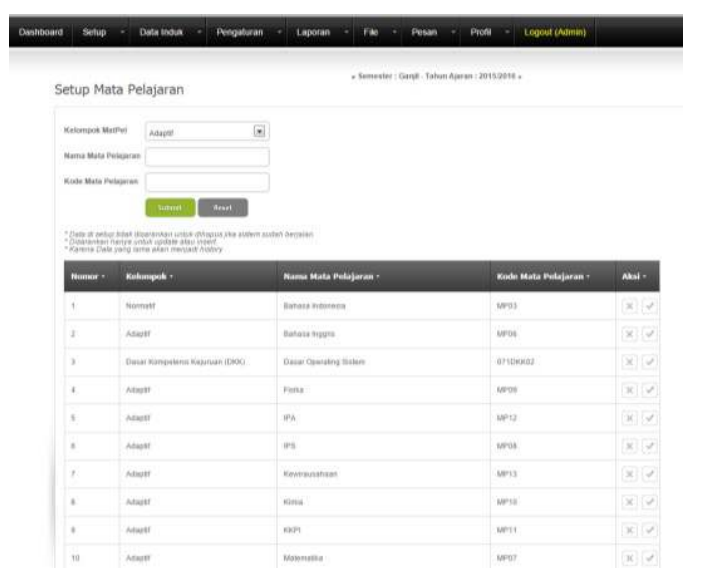

Gambar 4.2 Input mata pelajaran.

Halaman Input mata pelajaran merupakan halaman untuk memasukkan mata pelajaran ke dalam database.

Gambar 4.3 Input data siswa.

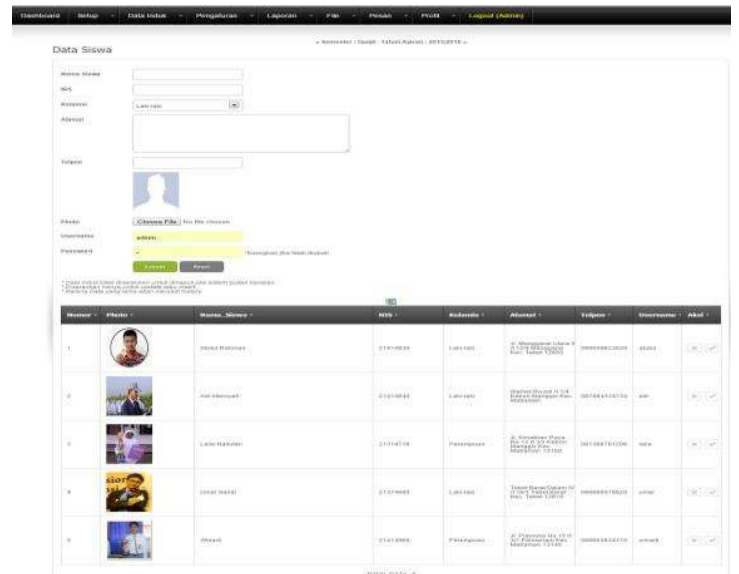

Gambar 4.3 Input data siswa.

Halaman Input data siswa merupakan halaman untuk memasukkan data siswa ke dalam database.

Gambar 4.4 atur akses orangtua.

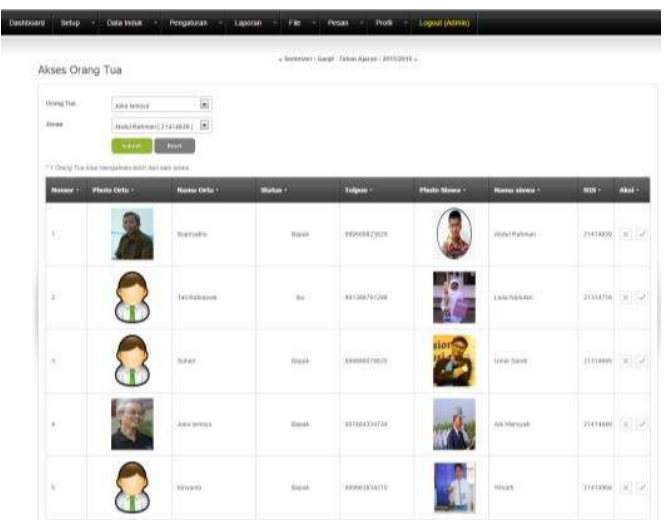

Gambar 4.4 atur akses orangtua.
Halaman akses orangtua merupakan halaman untuk mengatur akses orangtua sesuai dengan siswa.

Gambar 4.5 laporan admin.

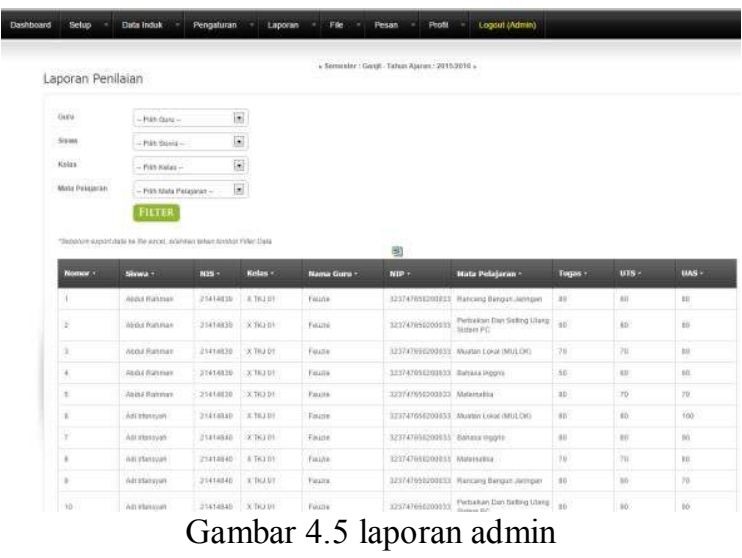

Halaman laporan merupakan halaman untuk melihat laporan data guru, data siswa, data orangtua, data nilai siswa. Laporan juga dapat di eksport ke dalam format excel.

Gambar 4.6 Input nilai.

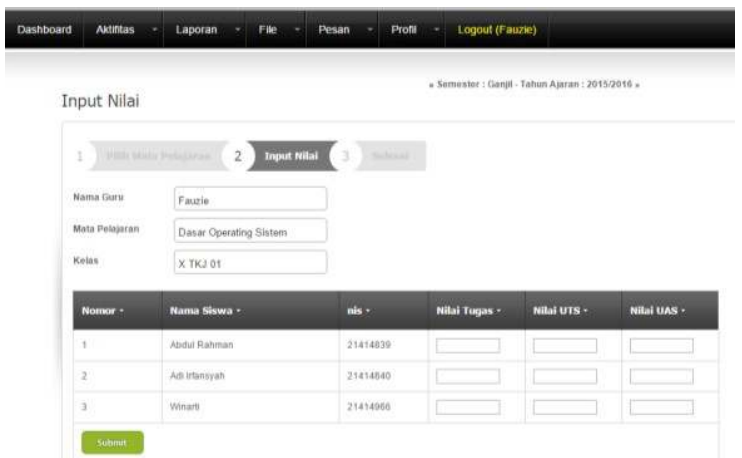

Gambar 4.6 Input nilai.

Halaman Input nilai merupakan halaman untuk Input nilai siswa oleh guru. Nilai berupa nilai rata - rata harian siswa, nilai UTS, dan nilai UAS.

Gambar 4.7 Laporan rekap nilai siswa. 


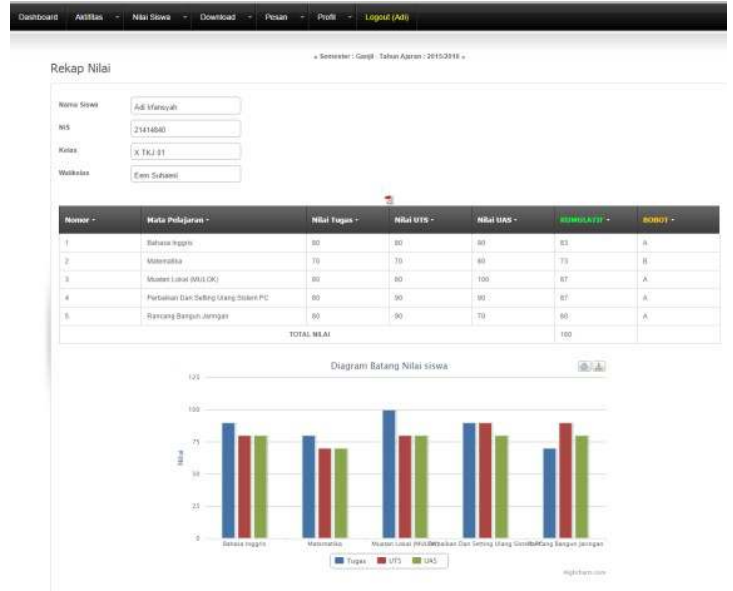

Halaman laporan rekap nilai siswa merupakan halaman untuk siswa melihat hasil nilai selama satu tahun pelajaran. Nilai berupa nilai rata - rata harian siswa, nilai UTS, dan nilai UAS permata pelajaran dalam bentuk tabel dan grafik nilai. Laporan nilai dapat di eksport ke dalam format PDF.

\subsection{Implementasi Rancangan Database}

Pada model data relasional hubungan antar tabel direlasikan dengan kunci utama (primary key) dari masing - masing tabel. Relasi antar tabel pada sistem yang dibangun dapat dilihat pada Gambar 4.8 .

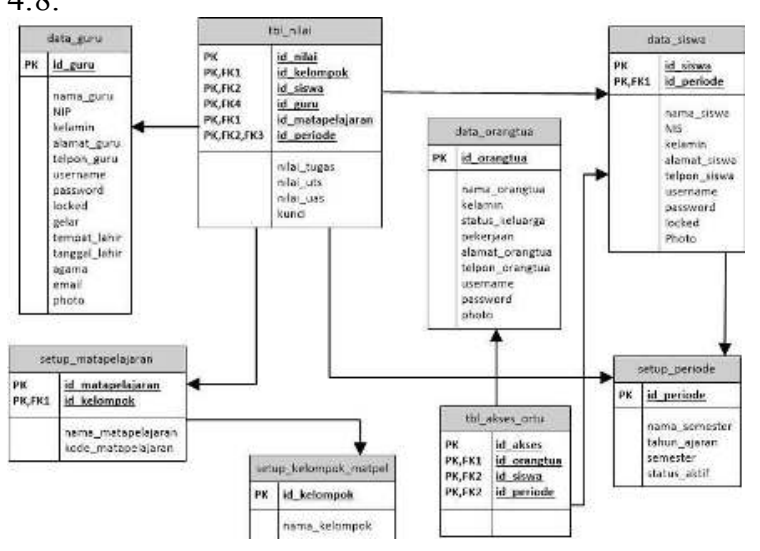

Gambar 4.8 Tabel Relasional.

DFD level 0 menggambarkan fungsi - fungsi utama atau menunjukan proses, aliran data dan external entity.

Gambar 4.9 DFD level 0.

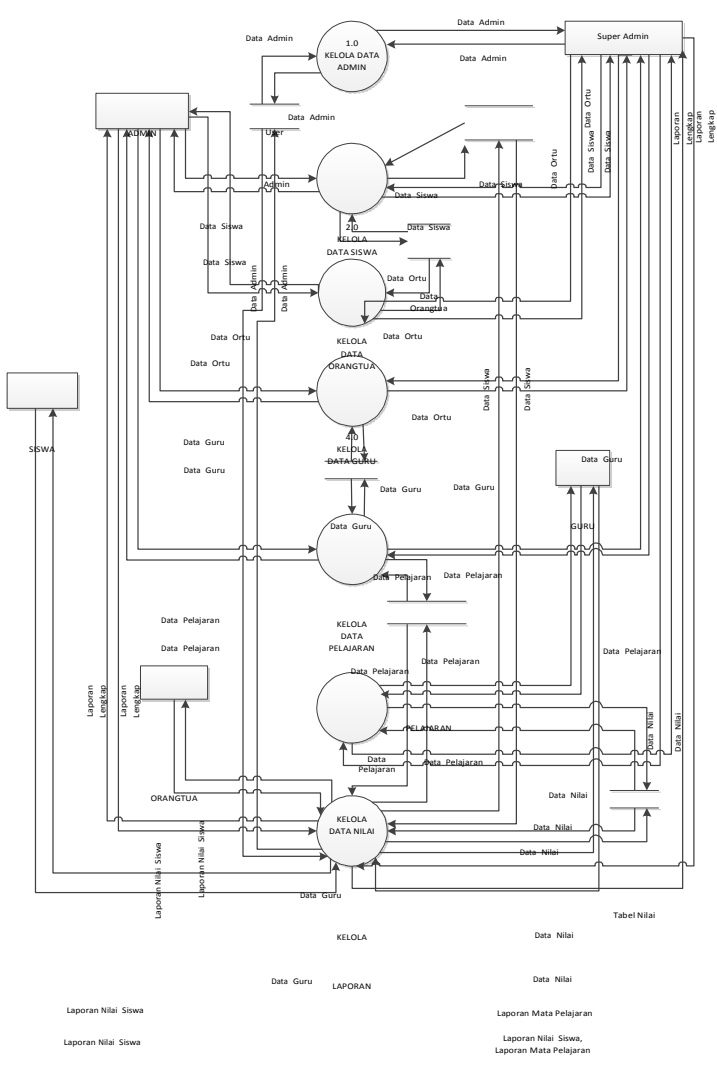

Gambar 4.9 DFD Level 0.

\subsection{Integrasi Sistem ke Web Server}

Untuk mencapai tujuan yang sempurna dari pembuatan sistem informasi nilai siswa, langkah terakhir adalah mengintegrasikan sistem dan database ke server hosting. Sebelumnya, SMK Karya Guna Jakarta telah menyewa domain, dan hosting di dapurhosting.com.

Gambar 4.10 Server hosting dapurhosting.com.

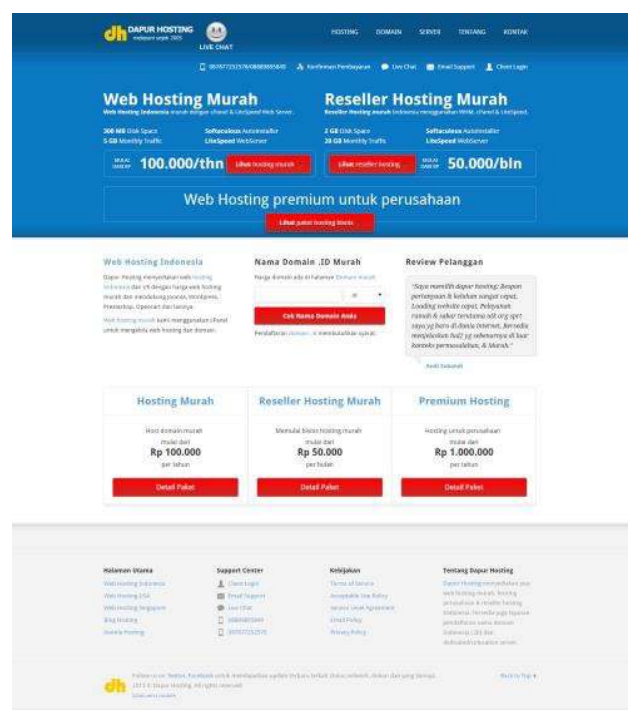

Gambar 4.10 Server hosting.

Pada gambar 4.29 menampilkan situs web server Dapur Hosting. Untuk memenuhi spesifikasi sistem yang menampung banyak data, serta banyak 
dengan kapasitas penyimpanan 5 Giga Byte, dengan Bandwidth unlimited. Paket yang disewa sudah termasuk domain, serta berbagai fitur tambahan lainnya salah satunya adalah backup data otomatis secara berkala.

\subsection{Pengujian Fungsional Sistem}

Pengujian bertujuan untuk memastikan sistem dapat berjalan dengan baik dan tidak terdapat kesalahan. Pengujian dilakukan dengan metode black box yang merupakan metode pengujian yang berfokus pada persyaratan fungsional sistem selama tahap akhir pengujian. Hasil pengujian Sistem Informasi Nilai Siswa Berbasis Web di SMK Karya Guna Jakarta menunjukkan bahwa sistem berjalan dengan baik sesuai dengan fungsinya dan tidak terdapat kesalahan teknis.

\section{Kesimpulan dan Saran}

\subsection{Kesimpulan}

Berdasarkan pembahasan dan analisa pada bagian sebelumnya, maka dapat ditarik kesimpulan bahwa:

1. Sistem informasi nilai siswa berbasis web dapat dibuat sesuai dengan perancangan yang telah dibuat.

2. Sistem dapat berjalan untuk pengolahan nilai siswa dan dapat di akses oleh user melalui komputer, laptop, PDA dan handphone yang terhubung dengan jaringan Internet.

\subsection{Saran}

Saran - saran yang dapat peneliti berikan berdasarkan analisis dan kesimpulan yaitu:

1. Perbaikan terhadap struktur database yang lebih sederhana agar dapat mengolah jumlah data yang lebih banyak lagi.

2. Menambahkan fitur seperti kuesioner guru, untuk membantu dalam mengevaluasi cara mengajar seorang guru.

3. Pengaturan jadwal ujian, agar siswa dapat mengetahuai informasi ujian dari sistem.

4. Menambahkan pengumuman, untuk siswa mengetahui informasi apa yang ada di Sekolah.

5. upload dan download materi serta tugas siswa, agar sistem dapat membantu kegiatan akademik lebih baik lagi.

\section{Daftar Pustaka:}

Al Fatta, Hanif. 2007. Analisis dan Perancangan Sistem Informasi. C.V Andi Offset. Yogyakarta.

Ariyus dan Dony. 2006. Computer Security. C.V Andi Offset. Yogyakarta.

Dukom, Master. 2011. Menjadi Master Website dalam Hitungan Menit. Bekasi-Jawa Barat. Dunia Komputer.

Fakultas Teknik. 2012. Buku Pedoman Skripsi/Komprehensif/Karya Inovatif (S1). Fakultas Teknik, Universitas Negeri Jakarta.

Saputra, Agus. 2012. Sistem Informasi Nilai Akademik. PT. Elex Media Komputindo. Jakarta.

Jogiyanto. 2005. Sistem Teknologi Informasi. C.V Andi Offset. Yogyakarta.

Kadir, Abdul. 2006. Dasar Aplikasi Database MySQL Delphi. C.V Andi Offset. Yogyakarta.

Kusrini. 2007. Strategi Perancangan dan Pengelolaan Basis Data. C.V Andi Offset. Yogyakarta.

Raharjo, Budi. 2011. Belajar Pemrograman Web, Modula. Bandung.

Wikipedia. 2015. Flowchart. [Online]. Tersedia: https://id.wikipedia.org/wiki/Diagram_alir\# cite note-SSEV-1

Wikipedia. 2015. Entity Relathionship Diagram. [Online]. Tersedia: https://id.wikipedia.org/wiki/Diagram_hub ungan entitas 